\title{
Statement Of Feminism Movement Figure In Novel : Aisyah " Wanita Yang Hadir Dalam Mimpi Rasulullah"
}

\author{
Diana Rumondang Siregar ${ }^{1}$, Kristina Siringo-Ringo ${ }^{2}$, Nursitta Situmorang ${ }^{3}$, Fachri Yunanda ${ }^{4}$ \\ 1,2,3,4 Universitas Prima Indonesia \\ Email: dianarumondang686@gmail.com ${ }^{1}$, kristinasiringo6@gmail.com² , \\ nursittasitumorang1122@gmail.com ${ }^{3}$, faym2c@gmail.com ${ }^{4}$
}

\begin{abstract}
This study aims to describe the characterization of feminism movement figures in Sibel Eraslan's novel "Aisyah ( Wanita Yang Hadir Dalam Mimpi Rasulullah )", which reflects the reality of women's lives and the struggle for equality between men and women. The author is interested in researching this novel, because this novel is able to present wise or intelligent female characters in carrying out feminist movements to break down those who narrow the space for women's movements by using the feminist literary criticism approach. The research data is qualitative data in the form of facts, information, statements or descriptions obtained by researchers from research sources, namely the novel Aisyah ( Wanita Yang Hadir Dalam Mimpi Rasulullah ) by Sibel Eraslan. The data collection technique uses descriptive qualitative methods that focus on content analysis, which is an in-depth analysis of the content of written information.
\end{abstract}

Key words: Content Analysis, Feminist Movement, Novel.

\section{INTRODUCTION}

Literary work is a reflection or description of people's life that was expressing in language, both oral and written, which has beauty. Through literary works, writers usually show or raise the joys and sorrows of people's lives they feel. Inside it is full of meaning that must explored through in-depth research as well (Endraswara, 2003). The literary works created by the author that should able be enjoyed, understood, lived and used by the community. Literary work itself that has created from the imaginations of the author and uses everything on earth as its object.

Literature has the freedom to convey the truth. Literary identity is a form of knowledge that is different from science, philosophy and religion. Literature has its own way of conveying the thoughts of the author. Hence, literature and value systems are two things side by side. The relevance between literature and value systems expressed in the literary formulation itself (Latifi, 2016)

The use of female objects is often found in literary works. Women with all their uniqueness, strengths and weaknesses are often discussed in literary works, the use of female objects in literary works cannot be separated from the study of feminism which is often voiced by women

Often times in literature, women was describing as the second sex or patriarchal attitudes that have been pass down from generation to generation and are still very strong among certain societies. Describes women as obedient people and thinks that it's good for women only to work at home. Even when women want to work, the women assume that they are disobedient, or violate the social order that has been held tightly by patriarchs.

Sibel Eraslan, a Turkish development writer, is famous for his phenomenal works not only in his country but the world has enjoyed his works, his most phenomenal works include Khadijah: Ketika Rahasia Mim Tersingkap , Fatimah Az- Zahra: Kerinduan Dari Karbala, Asiyah: Sang Mawar Gurun Firaun, Maryam Bunda Suci Sang Nabi. And the latest work written by Sibel Eraslan is Aisyah: Wanita Yang Hadir Dalam Mimpi Rasullullah. In each Sibel Eraslan's works, he often tells about the history of a woman's struggle.

Therefore, researchers are interesting in researching in novel: Aisyah ( Wanita Yang 
Hadir Dalam Mimpi Rasulullah ) written by Sibel Eraslan. Where the researchers focused on the main shop, namely Aisyah. By using a feminist theory approach as a framework for proposing to answer research problems. The research data is qualitative data in the form of facts, information, statements or descriptions obtained by researchers from the main source of the research, namely the novel: Aisyah ( Wanita Yang Hadir Dalam Mimpi Rasulullah ). The data collection technique uses descriptive qualitative methods that focus on content analysis, which is in-depth analysis, comparison between data, categorization, data presentation and making inferences on the content of written information. the validity the data was carring out through repeated reading (semantic validity), references to source books (referential validity), and discussion with peers (interrater reliability) (Syarifuddin, 2019)

\section{REVIEW OF LITERATURE}

\section{Literature}

Etymologically, the word literature in Indonesian (in English it is often called literature and in French is called literature) comes from Sanskrit: the root word sās- in a derivative verb which means "to direct, teach, give instructions or instructions". Suffix -tra which denotes "tools or means". So literature can mean "a tool for teaching, manuals, instruction books or teaching" (Widayat, 2004). Based on the above statement, it can be concluded that literature is one of the learning tools that can be applied.

(Sumardjo \& Saini KM, 1986) literature is an expression of the human person in the form of experiences, thoughts, feelings of ideas, enthusiasm, beliefs in a form of concrete images that evoke fascination with language tools. This opinion can be interpreted that literature is an expression of human feelings in the form of something real by using language as a tool. In addition, according to (Sumardjo \& Saini KM, 1986) literary work is an attempt to record the contents of the literary soul. This recording uses language tools. Literature is a recorded form in the language that the author will convey to the reader.

Based on the above statement, it can be concluded that literature is one of the learning tools that can be used by society. A writer can use his ideas, ideas, thoughts to convey the anxiety he feels by using language as a tool to convey this information. In literary works, there are intrinsic elements that are very important. According to Pradopo (Sugihastuti \& Suharto, 2002) to be able to understand literary works (novels), literary works (novels) must be analyzed for their intrinsic structure. That way, the next theory will be discussed in more detail about the elements of literary works.

\section{Novels and the Elements of the novel}

a. Novel

Knickerbocker and Reniger argue (Hoed, 1992) that a novel is a creative work, that is, it presents not a reality in this world, but a symbol of that reality. Based on the above explanation, it can be concluded that what is presented in the novel is not reality or is also called fiction or fictional work, which is basically a creation. Compared to other literary works such as poetry, short stories, novelets, and others. Novels are better able to tell a variety of issues or more complex life issues. The intrinsic elements of the novel are:

1) Theme

(Zulfahnur, Firdaus, Sayuti Kurnia, Yuniar Z, \& Adji, 19996) suggest that the term theme comes from the English theme which means an idea that is the subject of a discussion or the main idea of a writing. Themes are the central idea that underlies a story. Themes have three functions, namely as a guide for writers in making stories, the goals of story development, and binding story events in a plot.

According to (Semi, 1993), the theme is a central idea that becomes the basis and purpose or mandate of the author to the reader. According to (Nurgiyantoro, 2016)themes are the main ideas or ideas that 
underlie literary works. Themes are not the main meaning of fiction. However, the theme is the whole meaning that is supported by the story, by itself it will be hidden behind the story that supports it.

2) Figures

A discussion in a work of fiction, in a novel Aisyah: ( Wanita Yang Hadir Dalam Mimpi Rasulullah ). terms such as character and characterization, character and characterization, or character and characterization will be used. The term character is shown to the actor of the story or the person, while characterization and characteristics show the character or nature of the actor in the story. The characters, according to Abrams (Nurgiyantoro, 2000), are the people who are shown in a narrative work, or drama, which the reader interprets as having certain moral qualities and inclinations as expressed in speech and what is done in action. From the above quote, it is a character with personal qualities related to the acceptance of readers.

In this case the reader will give all meaning. Story characters occupy a strategic position as carriers and transmitters of messages, messages, or something that is intentionally conveyed to readers (Nurgiyantoro, 2010). Based on the description above, it can be concluded that the character of the story can be said to be the actor of the story who expresses his expression through words or actions in the work of fiction. A character is the most important element in a literary work, because a character is a story actor whose function is to convey a message to the reader.

3) Characterization

Characterization and Modeling are closely related. Characteristics relate to the way the author determines and selects the characters and names the characters. Characteristics relates to how the characters are characterized. Characterization are often equated in meaning with characters and characterizations that refer to the placement of certain characters with certain characters in a story, or as said by Jones (Nurgiyantoro, 2010). Stanton (Nurgiyantoro, 2010). The term characterization is broader in meaning than character and characterization, because characterization also includes the problem of who the character of the story is, how it is described, and how to place and describe it in a story so that it can provide a clear picture to the reader. Characterization at the same time advises on techniques for embodying and developing characters in a story.

In the novel: Aisyah "Wanita Yang Hadir Dalam Mimpi Rasullullah" the researcher will reflect on the characterization of the main character, namely Aisyah as described by the author, both in terms of shop quality, quality of reason and spirit. Characterization here also refers to the description of the quality of character behavior that is displayed in a story (Herdayanti, 2016)in other words, the person of a character in a work of fiction is called representation, while characterization means characterization, characterization. The meaning of representation in this sense is what researchers want to emphasize (Syarifuddin, 2019).

4) Setting

The presence of a setting is very important in a work of fiction. Because the presence of a character requires a place, time and space setting in a work of fiction. (Suroto, 1989)says the setting is a description of the situation, place and time and the atmosphere of the event. Furthermore, (Sumardjo \& Saini KM, 1986) defines the setting not only to designate a certain place, or time, but also the essential things of a region, to the kinds of dust, the thoughts of the people, their activities and so on.

The background elements in a work of fiction are divided into 3 , namely the setting of place, time and social / atmosphere. These 
three elements are very important because they are related and influence each other. The setting of the place is the location of the events that are told in a work of fiction, while the time setting is the time when the events occur in the work of fiction, and the social setting/atmosphere is related to the social behavior of the community somewhere in the work of physics.

5) Plot

With a good plot that will make it easier for readers to relate the story to the story that is written, Flot also directs the reader to understand the story by describing the story from the beginning to the end of the story made by the author. Flow can increase the reader's level of understanding in the events in the story. In understanding the storyline, there are several things that will be included, namely:

a) The opening plot is the flow where the story is explained about the beginning of the story until the continuation of the story that will take place next.

b) The middle plot, which is the plot at the beginning of the explanation of the story in the character of the character by explaining the beginning from the cause of the problem to causing conflict between the characters.

c) The top flow is a plot that explains what things happen in the problem, both negative, conflict and even violence in the story.

d) The closing flow, namely the flow of looking for a way out in resolving conflicts or problems between the characters in the story, until the final stage of the story ends with a happy ending.

With the explanation of the stage of the storyline, it can be concluded that in a story, the initial causes of the story will begin to conflict in the problem and what things happen in the story until the problem solvers are found in the characters. In the plot, we can understand that every story must always have a connection between each character and one another with this connection, it will cause a conflict of problems in the story.

According to one expert, (Atar, 1993)says that the plot or plot is the structure of a series of events in a story that is arranged as a functional interrelation which also marks the order of the parts in the whole fiction..

\section{Feminist literary criticism}

Feminist etymology comes from the word femme (woman) which means women who aim to fight for women's rights. Feminist goals are to increase the position and degree of women to be equal to men. (Djajanegara, 2000). (Humm, 1990), states that feminism is an ideology of women's liberation because what is inherent in all her approaches is the belief that women experience injustice because of gender. So feminists aim to balance or equalize the rights of women and men..

According to Yoder (Sugihastuti \& Suharto, 2002)feminist literary criticism does not mean criticizing women, or criticism of female authors. Feminist literary criticism is a criticism of literary works with the awareness that there are genders that have a lot to do with culture, literature, and life. Feminist and gender issues are basically equal rights. Gender is cultural psychological, as a difference between masculine-22 feminism, while sex is physiological, in nature, as a difference between male-female (Andrew Edgar and Peter Sedgwick, through (Ratna \& Nyoman Kutha, 2004). Based on the quotation above, it can be concluded that gender is a matter of rights while sex is natural gender. Feminism is a social study involving oppressed women. Feminism is a movement of women to obtain freedom for themselves.

According to (Endraswara, 2003)literary works with feminist nuances will automatically move to emancipation, the final activity. Feminist struggle is equality, which wants to place women not as objects. So feminist literature studies still pay attention to gender 
issues. According to Kasiyan (Sugihastuti \& Itsna Hadi Setiawan, 2010)feminism as a women's movement appears in different characteristics due to basic assumptions that view issues that cause gender inequality.

Sibel Eraslan is one of the writers who has written many histories of women's struggles which she applies through literary works, namely novels. Many of the works are used as references for those who are active in discussing women's struggles or those who are active in feminism.

\section{METHODOLOGY}

The method used in this research is descriptive qualitative method, which emphasizes notes with detailed, complete, indepth descriptions of sentences that describe the actual situation to support the presentation of data (Nugrahani, 2014)This method focuses on content analysis, which is an in-depth analysis, comparison between data, categorization, data presentation and making inferences on the content of written information. The validity of the data was carried out through repeated reading (semantic validity), references to source books (referential validity), and discussions with peers (interrater reliability) (Nurgiyantoro, 2016).

The form of research used is qualitative research that prioritizes appreciation of the interaction between concepts being studied empirically (Karomah, Martono, \& Wartiningsi). In this case, the researcher is directly dealing with literature as a source of data, in this study the data is collected in the form of words or sentences and not in the form of numbers. The approach used in this study is a feminist literary criticism theory approach, namely by analyzing the text in the Novel: " Aisyah (Wanita Yang Hadir Dalam Mimpi Rasulullah ). With techniques that move from (1) analysis of the structure of the novel Aisyah ( Wanita Yang Hadir Dalam Mimpi Rasulullah ); (2) analysis of main shop figures in Novel: "Aisyah ( Wanita Yang Hadir Dalam Mimpi
Rasulullah ); (3) examines Aisyah's statement which embodies feminism in the Novel: " Aisyah (Wanita Yang Hadir Dalam Mimpi Rasulullah). While the research data is qualitative data in the form of facts, information, statements or descriptions obtained by researchers from the main source of research, namely the novel Aisyah ( Wanita Yang Hadir Dalam Mimpi Rasulullah ) by Sibel Eraslan.

\section{DISCUSSION AND RESULTS}

Sibel Eraslan, a Turkish development writer, is famous for his phenomenal works not only in his country but the world has enjoyed his works, his most phenomenal works include Khadijah: Ketika Rahasia Mim Tersingkap , Fatimah AzZahra: Kerinduan Dari Karbala, Asiyah: Sang Mawar Gurun Firaun, Maryam Bunda Suci Sang Nabi. Dan karya terbaru yang ditulis oleh Sibel Eraslan ialah Aisyah: Wanita Yang Hadir Dalam Mimpi Rasullullah. In each Sibel Eraslan's works, he often tells about the history of a woman's struggle.

Therefore, researchers are interesting in researching in novel: Aisyah ( Wanita Yang Hadir Dalam Mimpi Rasulullah ) written by Sibel Eraslan. Where the researchers focused on the main shop, namely Aisyah. By using a feminist theory approach as a framework for proposing to answer research problems. The research data is qualitative data in the form of facts, information, statements or descriptions obtained by researchers from the main source of the research, namely the novel: Aisyah ( Wanita Yang Hadir Dalam Mimpi Rasulullah ). The data collection technique uses descriptive qualitative methods that focus on content analysis, which is in-depth analysis, comparison between data, categorization, data presentation and making inferences on the content of written information. the validity the data was carring out through repeated reading (semantic validity), references to source books (referential validity), and discussion with peers (interrater reliability) (Syarifuddin, 2019) 
"Aisyah, child is full of curiosity. Aisyah is a never-ending question "Sibel Eraslan (2019, page 29)

In Aisyah's family, both men and women are treat equally. Aisyah is allow to ask any questions from her ancestors, including knowledge and so on.

"Not only men know how to read and write as well as count and historical knowledge. The women in our family are also taught to learn, read, memorize and know the manners of speaking politely as taught to men "Sibel Eraslan (2019, page 17).

"I am a girl who is allow talk to wise elder figures. I always have the opportunity to talk and ask questions, especially about polite and civilized rules. "Sibel Eraslan (2019, page 28)

Aisyah grew up in a loving family and did not differentiate between women and men and did not limit the space between women and men. This pattern of life made Aisyah's character or character very smart and wise and she paid attention to her environment. Without exception pay attention to welfare and get justice between women and men.

"The women are equally enthusiastic than the men in terms of learning. We have heard advice like this "the reward for someone who teaches modesty to his family is to get double the reward for teaching someone else." This understanding means that everyone who teaches is a teacher in their respective homes. Women and children also have very strong intentions in learning "Sibel Eraslan (2019, page 162)

Look at how Aisyah really cares about education for all people, not only men who are active in learning, women are also required to study.

We Arabs are very freedom-minded. We are not people who like being ordered around or pressured. However, the current generation has become very self-respecting people and it is difficult to listen to what others say. We were taught the idea of equality as the most appropriate reason for accepting Islam as well as being our means of preaching. Similarities are the most valuable thing for us but also a test for us "Sibel Eraslan (2019, page 453).

The above expression shows how much Aisyah cares for freedom and equality. However, the above expression also shows Aisyah's worry for the next generation who place great importance on self-esteem and find it difficult to listen to other people's opinions.

However, her feminine figure is still in Aisyah, look how Aisyah is very jealous of Khadijah, the first wife of the Rasullulah.

"If I say that Khadija is the person most cherished and loved by Rasulullah, that actually still seems a little. Talking about Khadijah really makes me jealous "Sibel Eraslan (2019, page 362).

However, Aisyah's jealousy does not make Aisyah an annoying person, in other words, Aisyah can always overcome her jealousy with help or warnings from Rasullulah.

"Even though I died, I still sometimes feel jealous of him. But when that was the case, the Rasullulah often warned me, and immediately I regretted it and handed over the irreplaceable place in the messenger of Rasullulah to this mother "Sibel Eraslan (2019, page 362)

\section{SUGGESTION AND CONCLUSION}

\section{SUGGESTION}

Based on the results of the analysis, the researcher provides the following suggestions. (1) For teachers, it is hope that the teaching of English language and literature will be able to use the results of this study as teaching materials in school learning, especially at the SMA class XI semester I, on learning intrinsic elements in novels The teacher can choose the novel Aisyah ( Wanita Yang Hadir Dalam Mim pi Rasulullah ) as an object of learning in the delivery of material elements in the novel. Because in the novel have life values such as the trials and struggles of the main female character in dealing with problems in their lives, which should emulated by students and have intrinsic elements that could be studied. (2) For readers, it is hope that they can reap the values 
found in this research on feminism. (3) For researchers, it is hope that the results of this research can increase knowledge about the study of feminism contained in literary works.

\section{CONCLUSION}

Depiction of the feminist movement figure in the novel Aisyah (Wanita Yang Hadir Dalam Mimpi Rasulullah) by Sibel Eraslan is intensively seen in the main character, Aisyah, who has a character or character who cares about science and social matters. Aisyah has a high desire to know about knowledge and at the same time she is very rebellious against injustice against women and puts forward education, freedom and equality for all circles, both women and men. However, Aisyah's wise character does not diminish Aisyah's womanly nature. However, Aisyah's jealousy doesn't mean that Aisyah is irrational in making decisions.

The above expression has supported the focus of this research, namely Feminism with the Feminist literary criticism approach. According to Suwardi (2008: 146), literary works with feminist nuances will automatically move to emancipation, the final activity. Feminist struggle is equality, which wants to place women not as objects. So feminist literature studies still pay attention to gender issues. According to Kasiyan (in Sugihastuti and Itsna Hadi Saptiawan, 2007: 86-89) feminism as a women's movement appears in different characteristics due to the basic assumption that views issues that cause gender inequality. So it can be concluded that this analysis is in according with what was stating by Suwardi that Aisyah really cares about equality between women and men in terms of getting justice both educational, scientific and social.

\section{REFERENCES}

Atar, S. (1993). Anatomi Sastra Bandung. Angkasa Raya.

Djajanegara, S. (2000). Kritik Sastra Feminis Sebuah Pengantar. Jakarta: Gramedia Pustaka Utama.
Endraswara, S. (2003). Metode Penelitian Satra: Epistemologi, Model, Teori dan Aplikasi. Yogyakarta: Pustaka Widyatama.

H Benny, H. (1992). Kala Dalam Novel Fungsi dan Penerjemahan. Yogyakarta: Gadjah Mada University Press.

Herdayanti, Y. (2016). Alur dan Watak Tokoh Utama Dalam Kumpulan Cerpen Netizen Karya Rahman Dkk. Jurnal Pendidikan dan Pengajaran Untan, 117.

Hoed, H. B. (1992). Kala Dalam Novel Fungsi dan Penerjemahanya. Yogyakarta: Gadjah Mada University Press.

Humm, M. (1990). Dictionary Of Feminis Theories. Ohio: Ohio State University Press.

Karomah, D. I., Martono, \& Wartiningsi, A. (n.d.). Citra Perempuan Pada Autobiongrafi Perempuan Harem Karya Fatima Mernissi.

Latifi, Y. N. (2016). Rekonstruksi Pemikiran Gerder dan Islam Dalam Sastra: Analisis Kritik Sastra Feminis Terhadap Novel Zaynah Karya Nawal As-sa'dawi. Jurnal Musawa IAIN Palu , 72-250.

Nugrahani, F. (2014). Metode Penelitian Kualitatif. Surakarta.

Nurgiyantoro, B. (2000). Teori Pengkajian Fiksi. Yogyakarta: Gdjah Mada University PRESS.

Nurgiyantoro, B. (2016). Transfortasi Cerita Wayang Dalam Novel Amba dan Pulang. Litera.

Ratna, \& Nyoman Kutha. (2004). Teori, Metode, dan Tehnik Penelitian Sastra. Yogyakarta: Pustaka Pelajar.

Semi, A. (1993). Anatomi Sastra Bandung. Angkasa Raya.

Sugihastuti, \& Itsna Hadi Setiawan. (2010). Gender dan Inferioritas Perempuan: Praktik Kritik Sastra Feminis. Yogyakarta: Pustaka Pelajar. 
Sugihastuti, \& Suharto. (2002). Kritik Sastra Feminis: Teori dan Aplikasinya. Yogyakarta: Pustaka Pelajar.

Sumardjo, J., \& Saini KM. (1986). Antologi Apresiasi Kesusastraaan . Jakarta: PT Gramedia.

Suroto. (1989). Teori dan Bimbingan Apresiasi Sastra Indonesia. Jakarta: Erlangga.

Syarifuddin. (2019). Perwatakan Tokoh Pergerakan Feminisme Dalam Novel Ahlam Al- Nisa Al- Harem Karya Fatima Mernissi ( Sebuah Kajian Strukturalisme Genetik ). Jurnal Adabiya 2.

Widayat, A. (2004). "Pengantar Pengkajian Sastra " Diktat Pada Mata Kuliah Pengantar Pengkajian Sastra. Jurusan Pendidikan Bahasa Daerah, FBS, UNY Yogyakarta. Jurnal Litera UNY Yogyakarta .

Zulfahnur, Firdaus, Sayuti Kurnia, Yuniar Z, \& Adji. (19996). Teori Sastra. Jakarta: Pustaka. 